\title{
Apparent digestibility of dry matter, organic matter, protein and energy of native Peruvian feedstuffs in juvenile rainbow trout (Oncorhynchus mykiss)
}

\author{
Abimael Ortiz-Chura ${ }^{1,2+}$, Ruth Milagro Pari-Puma ${ }^{3}$, Francisco Halley Rodríguez Huanca ${ }^{3 *}$ (D),
} María Esperanza Cerón-Cucchi ${ }^{1}$ and Marcelino Jorge Araníbar Araníbar ${ }^{3+}$

\begin{abstract}
Trout production is a growing activity in recent years but requires new alternative sources of feed to be sustainable over time. The objective of this research was to determine the apparent digestibility coefficient (ADC) of dry matter $(\mathrm{DM})$, organic matter $(\mathrm{OM})$, crude protein (CP) and digestible energy (DE) of kañiwa (Chenopodium pallidicaule Aellen), kiwicha (Amaranthus caudatus L), quinoa (Chenopodium quinoa Willd), beans (Phaseolus vulgaris L.), sacha inchi, (Plukenetia volubilis $\mathrm{L}$ ) and jumbo squid (Dosidicus gigas) meal in juvenile rainbow trout. The experimental diets were composed of a $70 \%$ basal diet and $30 \%$ of any raw materials. The ADC was determined by the indirect method using insoluble ash as a non-digestible marker. Jumbo squid, sacha inchi and quinoa showed the highest values of ADC (\%) of DM (84.5, 73.5 and 69.7), OM (89.1, 78.4 and 72.9), CP (93.2, 98.0 and 90.3), and DE (4.57, 4.15 and 2.95 Mcal/kg DM), respectively. The ADC values for kañiwa, kiwicha and bean were significantly lower. In conclusion, quinoa meal and jumbo squid meal have an acceptable digestibility but sacha inchi meal is a potential alternative for rainbow trout feeding in the future.
\end{abstract}

Keywords: Digestibility, Jumbo squid meal, Quinoa, Rainbow trout feed, Sacha inchi

\section{Background}

Trout production in Peru has experienced considerable growth during the last 10 years (7.5 times), and Puno region produced 43,290 tons lately ([PRODUCE] Ministerio de la Producción 2017). Production of organic trout is also being considered due to the increase in demand for organic aquaculture.

Trout feeding requires feeds with high protein and energy content, which are mostly covered with fishmeal and fish oil (NRC (National Research Council) 2011). The availability of these raw materials is decreasing and therefore prices are increasing (FAO (Food and Agriculture Organization of the United Nations) 2016). The

\footnotetext{
* Correspondence: halleyal@gmail.com

${ }^{\dagger}$ Abimael Ortiz-Chura and Marcelino Jorge Araníbar Araníbar contributed equally to this work.

${ }^{3}$ Facultad de Medicina Veterinaria y Zootecnia, Universidad Nacional del Altiplano, Av. Floral 1153, Puno, Peru

Full list of author information is available at the end of the article
}

current trend of trout producers is to reduce the inclusion of fishmeal in the rations and replace it with vegetable raw materials but must supply essential nutrients for optimal fish performance (Glencross 2011). If an acceptable trout production with alternative raw materials is achieved, then it will increase profits and maintain its sustainability (Li et al. 2006).

The successful use of vegetable ingredients as a partial replacement for fish meal has been documented by several researchers (Gomes et al. 1995; Kaushik et al. 1995; Kumar et al. 2011; Lund et al. 2011; Lech and Reigh 2012). In fact, some diets that include proteins of vegetable origin are capable of producing acceptable growth comparable to traditional diets based on fishmeal (Gaylord et al. 2007; Davidson et al. 2013). However, it is necessary to identify and determine the nutritional value of newly available plant resources that can be used in the formulation of diets for fish. 
The Andean grains such as kañiwa (Chenopodium pallidicaule Aellen), kiwicha, (Amaranthus caudatus L) and quinoa (Chenopodium quinoa Willd) contain proteins of high biological value and are the main source of protein and energy in the diet of the Andean people (Repo-Carrasco et al. 2003; RepoCarrasco et al. 2009; Molina-Poveda et al. 2015) since more than $80 \%$ of world production is carried out in Peru and Bolivia (Bazile et al. 2016). Likewise, beans (Phaseolus vulgaris L.) are an important source of nutrients in human nutrition (Barampama and Simard 1993; Prolla et al. 2010) and in aquafeeds (Rodríguez-Miranda et al. 2014).

Sacha inchi (Plukenetia volubilis L) produced in the Peruvian Amazonia has seeds rich in protein, oil and vitamins. The sacha inchi meal is an extruded byproduct obtained after the extraction of its oil which is used for beneficial purposes in humans as improving the lipid profile of patients with dyslipidemia (Garmendia et al. 2011). Because of its high content of proteins of nutritional value (Ruiz et al. 2013), sacha inchi becomes an attractive alternative for animal feed.

The squid (Dosidicus gigas) is an abundant marine resource and a potential source of protein in Perú. The squid meal is produced based on the residues from the slaughtering process and has been used as an ingredient in shrimp diet (Córdova-Murueta and García-Carreño 2002).

Evaluating the digestibility of novel raw materials is important not only because it determines the proportion of nutrients that are available for trout but also because it also allows us to know the proportion of waste that is eliminated in the aquatic environment. In addition, it is necessary for identified sources of organic feed ingredients to develop organic feed formulations to produce organic aquacultured products for this burgeoning market.

The objective of the present study was to determine the apparent digestibility of dry matter, organic matter, crude protein and digestible energy of five organically certified plant protein sources (kañiwa, kiwicha, quinoa, beans, sacha inchi) and a marine protein source (jumbo squid) in juvenile rainbow trout.

\section{Methods}

Location, experimental design and analytical determination All the experimental procedures were carried out in the Faculty of Veterinary of the National University of the Altiplano, Puno, Perú, at an altitude of 3828 m (15 49' $\left.29^{\prime \prime} \mathrm{S}, 70^{\circ} 00^{\prime} 56^{\prime \prime} \mathrm{W}\right)$. The digestibility test was performed in a water recirculation system $(0.5 \mathrm{l} / \mathrm{s})$ equipped with a closed water treatment system, gravel filter (STF Filtre System Leri Model 002737), activated carbon filter, biological filter (clays with Nitrifying Bacteria, Proline ${ }^{\odot}$ ) and UV filter (X-Ray UV Light Boyo ${ }^{\circ}$, China).

The system consisted of digestibility tanks (500 l capacity), each one provided with a sedimentation unit for fecal collection (Rodehutscord et al. 2000). The average water quality parameters were $\mathrm{pH}$ 8.6, temperature $12{ }^{\circ} \mathrm{C}$ (Peachimeter SI Analytics Lab $850^{\circ}$, Germany) and dissolved oxygen $6.2 \mathrm{mg} / \mathrm{l}$ (HI 9146 Dissolved Oxygen Meter HANNA ${ }^{\circ}$ ). A total of 198 juvenile rainbow trout from a commercial line (Troutlodge, USA) of 130 days of age were used, with an initial weight of $92.6 \pm 3.32 \mathrm{~g}$ and a total length (Ichthyometer, Aquatic Eco-Systems ${ }^{\circ}$ ) of $20.2 \pm$ $0.42 \mathrm{~cm}($ mean $\pm \mathrm{SD})$. The fish were randomly distributed in the digestibility tanks with an average load density of $4.4 \mathrm{~kg} / \mathrm{m}^{3}$. The small farmers used around stocking density of $10 \mathrm{~kg} / \mathrm{m}^{3}$. Before handling, the fish were placed in a smaller aerated tank containing tricaine methanesulfonate $(50 \mathrm{mg} / \mathrm{l})$ until they lost consciousness.

The chemical proximal composition of raw materials and experimental diets are shown in Tables 1 and 2, respectively. Seven diets were evaluated (basal diet and six experimental diets), and three tanks were considered per treatment (diet). The experimental diets were composed of a $70 \%$ basal diet and 30\% of any of the five vegetable raw materials (kañiwa, kiwicha, quinoa, beans and sacha inchi) organically certified by Bio Latina, Perú and an animal raw material (jumbo squid), according to the methodology proposed by (Glencross et al. 2007). The basal diet was formulated considering the nutritional requirements for trout (NRC (National Research Council) 2011). The ingredients were mixed and then extruded (Khal ${ }^{\circ}$ EE800, Germany). The apparent digestibility of the ingredients was determined by the indirect method using a non-digestible marker (Hyflo Super $\mathrm{Cel}^{\circ}$ ) according to (Rodehutscord et al. 2000). The test consisted of 10 days of habituation to the diet, to the environment and to the management and another 15 days of sample collection. The experimental diets were fed to the juveniles twice a day (10:00 and 16:00 h) until apparent satiety. After feeding, all waste of uneaten feed was collected and eliminated from the system and then excreta were collected directly from the sedimentation bottle. The experiment was carried out under a regime of natural light.

The novel ingredients, diets and feces, were analyzed according to the methodology of the (AOAC (Association of Official of Analytical Chemists) 2011). The dry matter was determined after drying for $4 \mathrm{~h}$ at $105^{\circ} \mathrm{C}$. In addition, gross energy (GE) was determined with a bomb calorimeter (Parr Instrument $6772^{\circ}$ USA). The indigestible marker in the diets and feces were determined 
Table 1 Chemical proximal composition of the novel raw materials

\begin{tabular}{|c|c|c|c|c|c|c|}
\hline Parameters (\%) & Kañiwa & Kiwicha & Quinoa & Bean & Sacha inchi & Jumbo squid \\
\hline Dry matter & $89.8 \pm 0.26$ & $91.0 \pm 0.18$ & $89.7 \pm 0.27$ & $90.2 \pm 0.37$ & $93.2 \pm 0.20$ & $90.5 \pm 0.82$ \\
\hline Organic matter & $95.5 \pm 0.01$ & $96.1 \pm 0.07$ & $96.6 \pm 0.02$ & $96.0 \pm 0.06$ & $94.5 \pm 0.02$ & $87.9 \pm 0.07$ \\
\hline Crude protein & $13.4 \pm 1.03$ & $15.4 \pm 0.74$ & $11.1 \pm 0.76$ & $21.9 \pm 0.44$ & $54.9 \pm 1.82$ & $72.0 \pm 0.33$ \\
\hline Crude lipid & $4.5 \pm 0.36$ & $7.5 \pm 1.14$ & $6.7 \pm 0.56$ & $4.1 \pm 0.19$ & $9.9 \pm 0.52$ & $3.5 \pm 0.97$ \\
\hline Fibre & $9.2 \pm 0.25$ & $7.5 \pm 0.79$ & $5.1 \pm 0.25$ & $4.8 \pm 0.26$ & $4.9 \pm 0.87$ & $2.2 \pm 0.35$ \\
\hline Carbohydrates $^{1}$ & $58.2 \pm 0.38$ & $56.6 \pm 0.90$ & $63.4 \pm 0.38$ & $55.4 \pm 0.47$ & $18.0 \pm 1.94$ & $0.6 \pm 0.51$ \\
\hline Ash & $4.5 \pm 0.01$ & $3.9 \pm 0.07$ & $3.4 \pm 0.02$ & $4.0 \pm 0.06$ & $5.5 \pm 0.02$ & $12.1 \pm 0.07$ \\
\hline Gross energy $^{2}$ & $4.64 \pm 0.04$ & $4.61 \pm 0.01$ & $4.53 \pm 0.01$ & $4.44 \pm 0.01$ & $5.25 \pm 0.02$ & $5.08 \pm 0.08$ \\
\hline
\end{tabular}

Values are means \pm SD for three replicates

${ }^{1} \mathrm{CH}=\mathrm{DM}-(\mathrm{CP}+\mathrm{CL}+\mathrm{F}+\mathrm{A})$

${ }^{2}$ Analyzed by combustion (Mcal/kg DM)

Table 2 The ingredients and chemical composition of experimental diets

\begin{tabular}{|c|c|c|c|c|c|c|c|}
\hline & \multicolumn{7}{|l|}{ Diets } \\
\hline & Basal & Kañiwa & Kiwicha & Quinoa & Bean & Sacha inchi & Jumbo squid \\
\hline \multicolumn{8}{|l|}{ Ingredients, \% } \\
\hline Fish meal & 44.00 & & & & & & \\
\hline Kañiwa & & 29.61 & & & & & \\
\hline Kiwicha & & & 29.61 & & & & \\
\hline Quinoa & & & & 29.61 & & & \\
\hline Bean & & & & & 29.61 & & \\
\hline Sacha inchi & & & & & & 29.61 & \\
\hline Jumbo squid & & & & & & & 29.61 \\
\hline Soybean meal & 24.40 & & & & & & \\
\hline Corn meal & 8.00 & & & & & & \\
\hline Wheat middlings & 14.00 & & & & & & \\
\hline Fish oil & 8.00 & & & & & & \\
\hline Common salt & 0.30 & & & & & & \\
\hline Marker (Hyflo Super Cel $\left.{ }^{\circledast}\right)^{1}$ & 1.00 & 0.30 & 0.30 & 0.30 & 0.30 & 0.30 & 0.30 \\
\hline Premix $^{2}$ & 0.30 & 0.09 & 0.09 & 0.09 & 0.09 & 0.09 & 0.09 \\
\hline Basal diet & & 70.00 & 70.00 & 70.000 & 70.00 & 70.00 & 70.00 \\
\hline Total & 100.00 & 100.00 & 100.00 & 100.00 & 100.00 & 100.00 & 100.00 \\
\hline \multicolumn{8}{|l|}{ Analyzed composition (\%) } \\
\hline Dry matter & 93.3 & 93.4 & 92.1 & 93.3 & 93.1 & 91.9 & 90.4 \\
\hline Organic matter & 87.4 & 89.4 & 88.8 & 89.4 & 89.2 & 88.6 & 86.8 \\
\hline Crude protein & 40.0 & 32.4 & 34.1 & 32.8 & 35.4 & 44.1 & 48.9 \\
\hline Crude fat & 28.9 & 25.1 & 25.1 & 27.2 & 21.9 & 26.3 & 26.3 \\
\hline Ash & 12.6 & 10.6 & 11.2 & 10.6 & 10.8 & 11.4 & 13.2 \\
\hline Gross energy $^{3}$ & 5.29 & 5.08 & 5.19 & 5.03 & 5.03 & 5.29 & 5.29 \\
\hline
\end{tabular}

${ }^{1}$ Internal marker for determination of digestibility

${ }^{2}$ DSM Aquaculture Premix per $\mathrm{kg}$ of feed provided: Vitamins $\mathrm{A}=14,000 \mathrm{UI}, \mathrm{D} 3=2800 \mathrm{UI}, \mathrm{E}=140 \mathrm{UI}, \mathrm{K} 3=8 \mathrm{mg}, \mathrm{B}_{1}$ (thiamine) $=18 \mathrm{mg}, \mathrm{B}_{2}$ (riboflavin) $20 \mathrm{mg}$, Nicotinamide $=150 \mathrm{mg}$, Pantothenic acid $=50 \mathrm{mg}, B_{6}$ (pyridoxine) $=15 \mathrm{mg}$, Biotin $=0.8 \mathrm{mg}$, Folic acid $=4 \mathrm{mg}, C$ (ascorbic acid) $=600 \mathrm{mg}, B_{12}$ (cyanocobalamin) $=0.03 \mathrm{mg}$, Choline = $600 \mathrm{mg}$; and Minerals: Manganese $=40 \mathrm{mg}$, Iron = $20 \mathrm{mg}$, Zinc $=20 \mathrm{mg}$, Copper $1.5 \mathrm{mg}$, lodine = $1.5 \mathrm{mg}$, Selenium =0.3 mg, Cobalt =0.15 mg, BHT (butylated hydroxytoluene) $=120 \mathrm{mg}$

${ }^{3}$ Analyzed by combustion (Mcal/kg DM) 
according to the methodology proposed by (Scott and Boldaji 1997).

\section{Digestibility of dry matter, organic matter, protein and digestible energy}

The apparent digestibility of DM, OM, CP and DE of the experimental diets were determined using the equation (I) proposed by (Forster 1999).

$$
\mathrm{AD}(\%)=100-100 \times\left(\frac{\mathrm{MD}}{\mathrm{MF}}\right) \times\left(\frac{\mathrm{NF}}{\mathrm{ND}}\right)
$$

where $\mathrm{AD}$ is the apparent digestibility (\%), MD is the marker in the diet (\%), MF is the marker in the feces (\%), NF is the nutrient in the feces (\%) and ND is the nutrient in the diet (\%).

The digestibility of DM, OM, CP and DE of novel ingredients under study were estimated according to the equation (II) proposed by (Sugiura et al. 1998).

$$
\begin{aligned}
\operatorname{ADi}(\%)= & \mathrm{ADC}_{\mathrm{t}} \\
& +\left[\left(\frac{(1-\mathrm{s}) \mathrm{Db}}{\mathrm{s} \times \mathrm{Dt}}\right) \times(\mathrm{ADCt}-\mathrm{ADCb})\right]
\end{aligned}
$$

where $A D_{i}$ is the apparent digestibility of the ingredient under study (\%), $\mathrm{ADC}_{\mathrm{t}}$ is the apparent digestibility coefficient of the evaluated diet, $\mathrm{ADC}_{\mathrm{b}}$ is the apparent digestibility coefficient of the basal diet (\%), $D_{b}$ is the nutrients of the basal diet (\%), $D_{t}$ is the nutrients of the test diet (\%), $s$ is the proportion of the ingredient evaluated in the diet and 1-s is the proportion of the basal diet in the test diet.

\section{Statistical analysis}

The data analysis was performed using the analysis of variance procedure (ANOVA) in the SAS statistical program (SAS Institute Inc 2004). The digestibility means differences of the DM, OM, CP and ED among the kañiwa, kiwicha, quinoa, bean, sacha inchi and jumbo squid were compared by the Tukey test. The differences were considered significant at $P<0.05$.

\section{Results}

The apparent digestibility of $\mathrm{DM}, \mathrm{OM}, \mathrm{CP}$ and $\mathrm{DE}$ among the kañiwa, kiwicha, quinoa, bean, sacha inchi and jumbo squid were significantly different among the experimental diets and among the new raw materials studied (Table $3, P \leq 0.001$ ).

The experimental diets of jumbo squid, sacha inchi and quinoa had higher values of DM and OM digestibility than the diets containing kiwicha, kañiwa and beans. These results are consistent with the greater apparent digestibility of $\mathrm{CP}$ in diets containing sacha inchi meal (92.8\%), jumbo squid meal (91.3\%), quinoa meal (90.3\%) and kiwicha meal (90.1\%) and lower in the diets with kañiwa meal and bean meal. The DE value was also higher in the diets with jumbo squid meal (4.36 Mcal $/ \mathrm{kg}$ DM) and sacha inchi meal (4.19 Mcal $/ \mathrm{kg} \mathrm{DM})$ and lower in the diets with quinoa, kañiwa, kiwicha and bean meal.

Consequently, the apparent digestibility of DM and $\mathrm{OM}$ in novel raw materials was higher for jumbo squid and sacha inchi meals, followed by quinoa, kiwicha, kañiwa and bean meals. Consistent with the previous results, the apparent digestibility coefficient of CP was higher for sacha inchi (98.0\%), jumbo squid (93.2\%), quinoa (90.3\%) and kiwicha (89.1\%), followed by kañiwa meal (82.5\%) and bean meal (71.6\%). Consistently, jumbo squid (4.57 Mcal $/ \mathrm{kg} \mathrm{DM})$ and sacha inchi (4.15 Mcal $/ \mathrm{kg} \mathrm{DM}$ ) meals had also the highest values of $\mathrm{DE}$, while quinoa $(2.95 \mathrm{Mcal} / \mathrm{kg} \mathrm{DM})$, kiwicha $(2.74 \mathrm{Mcal} /$

\begin{tabular}{|c|c|c|c|c|c|c|c|c|}
\hline & \multirow[b]{2}{*}{ Basal } & \multicolumn{6}{|c|}{ Treatments } & \multirow[t]{2}{*}{ SEM } \\
\hline & & Kañiwa & Kiwicha & Quinoa & Bean & Sacha inchi & $\overline{J u m b o}$ squid & \\
\hline \multicolumn{9}{|l|}{ Diets (\%) } \\
\hline Dry matter & $72.9^{\mathrm{ab}}$ & $65.5^{d}$ & $68.8^{c d}$ & $72.1^{\mathrm{bc}}$ & $56.5^{\mathrm{e}}$ & $73.1^{\mathrm{ab}}$ & $76.3^{\mathrm{a}}$ & 1.11 \\
\hline Organic matter & $76.6^{\mathrm{ab}}$ & $68.3^{d}$ & $72.5^{c}$ & $75.4^{\mathrm{bc}}$ & $60.4^{e}$ & $77.2^{\mathrm{ab}}$ & $80.3^{\mathrm{a}}$ & 1.18 \\
\hline Crude protein & $90.3^{b}$ & $88.3^{c}$ & $90.1^{\mathrm{b}}$ & $90.3^{b}$ & $84.9^{d}$ & $92.8^{\mathrm{a}}$ & $91.3^{\mathrm{b}}$ & 0.40 \\
\hline Digestible energy $^{2}$ & $4.19^{b}$ & $3.57^{c}$ & $3.81^{d}$ & $3.78^{c}$ & $3.32^{\mathrm{e}}$ & $4.19^{\mathrm{b}}$ & $4.36^{\mathrm{a}}$ & 0.05 \\
\hline \multicolumn{9}{|c|}{ Novel raw materials (\%) } \\
\hline Dry matter & & $47.5^{d}$ & $58.9^{c}$ & $69.7^{b}$ & $36.6^{e}$ & $73.5^{\mathrm{b}}$ & $84.5^{\mathrm{a}}$ & 1.43 \\
\hline Organic matter & & $49.2^{\mathrm{e}}$ & $63.1^{d}$ & $72.9^{c}$ & $40.4^{f}$ & $78.4^{b}$ & $89.1^{\mathrm{a}}$ & 1.54 \\
\hline Crude protein & & $82.5^{d}$ & $89.1^{c}$ & $90.3^{b c}$ & $71.6^{\mathrm{e}}$ & $98.0^{a}$ & $93.2^{\mathrm{b}}$ & 1.14 \\
\hline Digestible energy ${ }^{2}$ & & $2.25^{\mathrm{d}}$ & $2.74^{c}$ & $2.95^{c}$ & $1.75^{\mathrm{e}}$ & $4.15^{b}$ & $4.57^{\mathrm{a}}$ & 0.09 \\
\hline
\end{tabular}

Table 3 Apparent digestibility of dry matter, organic matter, crude protein and digestible energy of diets and novel raw materials in juvenile rainbow trout (Oncorhynchus mykiss)

Means with different letters in the same row differ significantly at $P<0.05$

${ }^{1}$ Standard error mean $(n=3)$. The $P$ value in all variables studied in diets and novel raw materials were statistically significant $P<0.001$

${ }^{2}$ Expressed in Mcal/kg DM 
kg DM), kañiwa (2.25 Mcal/kg DM) and bean (1.75 Mcal/ $\mathrm{kg}$ DM) meals presented the lowest values.

\section{Discussion}

The apparent digestibility of DM, OM, CP and DE was significantly different between the raw materials of vegetable origin (sacha inchi, quinoa, kiwicha, kañiwa and bean) and that of animal origin (jumbo squid) used in this study. The lower digestibility of the DM and the $\mathrm{OM}$ of the vegetable ingredients can be explained by the higher content of fiber in its composition (4.8-9.2\%) than in the jumbo squid meal $(2.2 \%$, Table 1$)$. The levels of fiber in the vegetable ingredients are those that occur naturally, since these raw materials did not receive any previous treatment before the manufacture of the experimental feeds, except for sacha inchi meal that was extruded and defatted. The presence of antinutritional compounds such as saponins and tannins in plant feeds (Ruiz et al. 2013) also causes less nutrient digestibility (Gatlin et al. 2007). On the other hand, trout are carnivorous and therefore have a gut less specialized in the digestion of vegetable raw materials. However, since the extrusion was done to improve digestibility (Rodríguez-Miranda et al. 2014), the lower digestibility in the vegetable ingredients was attributed to higher fibre content. In fact, the digestibility of the protein depends on the methods of feed processing. The extrusion process improved the digestibility of the protein compared to pelleting in feed for trout (Fenerci and Sener 2005).

The digestibility value of the protein for squid meal in this study was similar to that reported for fishmeal (NRC (National Research Council) 2011; Gaylord et al. 2008). The higher protein digestibility of jumbo squid is attributed to the fact that feed from animal origin is with a high protein content (Córdova-Murueta and García-Carreño 2002) and also because trout are carnivorous fishes.

The sacha inchi meal had the highest values of digestibility among all the vegetable ingredients evaluated. This could be explained by the fact that it had been pre-processed (extrusion and extraction of oil). The integral seed of sacha inchi has around $24 \% \mathrm{CP}$ and $42 \%$ fat (Gutiérrez et al. 2011), while the extruded and degreased meal used in this study had $54.9 \%$ CP, 9.9\% fat and $5.25 \mathrm{Mcal} / \mathrm{kg} \mathrm{DM}$. In general, the CP and GE content of sacha inchi meal is similar to that of soybean meal solvent-extracted and cottonseed meal solvent-extracted. However, the results show that the digestibility of DM, $\mathrm{OM}, \mathrm{CP}$ and $\mathrm{DE}$ for sacha inchi was higher than for soybean meal (NRC (National Research Council) 2011; Glencross 2011; Gaylord et al. 2008) and cottonseed meal (NRC (National Research Council) 2011; Gaylord et al. 2008).

The apparent digestibility of DM, OM, CP (\%) and DE (Mcal/kg DM) of the 'Andean grains' were moderately high values, highlighting the apparent digestibility of DM and CP of quinoa meal (69.7 and 90.3, respectively). In a research carried out by (Muñoz et al. 2015) in juvenile fish Oplegnathus insignis, the apparent digestibility of DM and CP of quinoa was lower (64.1 and 80.2, respectively). In another study conducted by (MolinaPoveda et al. 2015) in shrimp Litopenaeus vannamei, they showed that fish meal can be replaced up to $45 \%$ with quinoa meal and only up to $15 \%$ with kiwicha meal without compromising the digestibility and performance. These results indicated to a greater digestibility of the $\mathrm{CP}$ in quinoa and lower in the kiwicha.

On the other hand, bean meal presented low digestibility values of $\mathrm{DM}, \mathrm{OM}, \mathrm{CP}$ and $\mathrm{DE}$, and this can be attributed mainly to the presence of antinutritional factors in its composition (Lech and Reigh 2012) that reduce the nutritional quality. The antinutritional factors can, however, be eliminated with thermal treatment and soaking (Pfeffer et al. 1995). The digestibility of CP $(71.6 \%)$ of the beans obtained in our study agrees with the studies carried out by (Tiril et al. 2009) for common bean (Phaseolus vulgaris L.) in juvenile rainbow trout (72.9\%). In vegetable ingredients, it is difficult to decrease the content of indigestible carbohydrates, which reduces the nutritional value in fish (Krogdahl et al. 2010). The functional properties of aquaculture feeds containing $15 \%$ bean meal were improved with the extrusion process $\left(120{ }^{\circ} \mathrm{C}\right.$ and $18 \%$ humidity) by Rodríguez-Miranda et al. 2014.

In general, digestibility values of $\mathrm{DM}, \mathrm{OM}, \mathrm{CP}$ and $\mathrm{DE}$ in new raw materials showed significant differences. The results suggest that the juvenile rainbow trout was more efficient in the digestion of the protein and energy of the jumbo squid and sacha inchi meal and less efficient in 'Andean grains' and beans. Probably the digestibility energy of plant vegetable ingredients could have been affected by intrinsic factors or amylose/ amylopectin ratio (Gomes et al. 1995; Gaylord et al. 2010). It is important to consider the value of the digestibility of raw materials in the preparation of diets for trout in order to reduce the release of fecal material and solids suspended in water (Davidson et al. 2013) as well as the feed wastage.

Finally, the most acceptable novel feeds for juvenile trout according to the digestibility values of the protein (\%) and the digestible energy (Mcal/kg DM) are sacha inchi meal (98.0 and 4.15), jumbo squid meal (93.2 and 4.57) and quinoa meal (90.2 and 2.95), respectively. Also, kiwicha meal presents intermediate values, while kañiwa and bean meal presented digestibility values less recommendable to be included in the ration of juvenile trout.

\section{Conclusion}

This study represents the first nutritional assessment of apparent digestibility coefficient of kañiwa, kiwicha, 
quinoa, sacha inchi and jumbo squid. Our results suggest that quinoa meal and jumbo squid meal have an acceptable digestibility and can be used in feed formulation but sacha inchi meal is a potential ingredient for the feeding of juvenile rainbow trout. Further researches are needed to evaluate the influence of these ingredients on growth performance and feed utilization in rainbow trout.

\section{Abbreviations \\ 1-s: Proportion of the basal diet in the test diet; ADC: Apparent digestibility coefficient; ADCb: Apparent digestibility coefficient of the basal diet; ADCt: Apparent digestibility coefficient of the evaluated diet; CONCYTEC: Consejo Nacional de Ciencia, Tecnología e Innovación Tecnológica; CP: Crude protein; Db: Nutrients of the basal diet; DE: Digestible energy; DM: Dry matter; Dt: Nutrients of the test diet; GE: Gross energy; MD: Marker in the diet; MF: Marker in the feces; ND: Nutrient in diet; NF: Nutrient in feces; OM: Organic matter; s: Proportion of the ingredient evaluated in the diet; SD: Standard deviation}

\section{Acknowledgements}

The authors wish to express their gratitude to CONCYTEC Perú (Consejo Nacional de Ciencia, Tecnología e Innovación Tecnológica) for the financial support they provided to carry out the research project.

\section{Funding}

This work was supported by CONCYTEC Perú (Consejo Nacional de Ciencia, Tecnología e Innovación Tecnológica) Project No. 287-2010.

\section{Authors' contributions}

AOC performed nutritional analysis discussion and wrote the initial version of the manuscript. RMPP performed the nutritional analysis. MECC contributed with study design. FHRH contributed in the data analysis, study design, discussion and writing. MJAA conceived and designed the study, supervised the work of $\mathrm{AOC}$ and contributed to the analysis, discussion and writing. All authors have reviewed and approved the final manuscript.

\section{Competing interests}

The authors declare that they have no competing interests.

\section{Publisher's Note}

Springer Nature remains neutral with regard to jurisdictional claims in published maps and institutional affiliations.

\section{Author details}

'Instituto de Patobiologia, Centro de Investigación en Ciencias Veterinarias y Agronómicas - INTA, Av. Nicolás Repetto y de los Reseros s/n (1686), Hurlingham, Buenos Aires, Argentina. ${ }^{2}$ Consejo Nacional de Investigaciones Científicas y Técnicas, Calle Godoy Cruz 2290 (C1425FQB), Buenos Aires, Argentina. ${ }^{3}$ Facultad de Medicina Veterinaria y Zootecnia, Universidad Nacional del Altiplano, Av. Floral 1153, Puno, Peru.

Received: 12 June 2018 Accepted: 31 August 2018

Published online: 20 November 2018

\section{References}

[PRODUCE] Ministerio de la Producción. Perú. Anuario Estadístico Pesquero y Acuícola 2017. Disponible en: http://ogeiee.produce.gob.pe/index.php/ shortcode/oee-documentos-publicaciones/publicaciones-anuales/item/775anuario-estadistico-pesquero-y-acuicola-2016; 203 p.

AOAC (Association of Official of Analytical Chemists). Official methods of analysis. 18th ed. Gaithersburg: Association of Official Analytical Chemists; 2011.

Barampama Z, Simard RE. Nutrient composition, protein quality and antinutritional factors of some varieties of dry beans (Phaseolus vulgaris) grown in Burundi. Food Chem. 1993:47:159-67. doi.org/10.1016/03088146(93)90238-B

Bazile D, Jacobsen SE, Verniau A. The global expansion of quinoa: trends and limits. Front Plant Sci. 2016;7:1-6. doi.org/10.3389/fpls.2016.00622
Córdova-Murueta JH, García-Carreño FL. Nutritive value of squid and hydrolyzed protein supplement in shrimp feed. Aquaculture. 2002;210(1-4):371-84. dx. doi.org/10.1016/S0044-8486(02)00011-X

Davidson J, Good C, Barrows FT, Welsh C, Kenney PB, Summerfelt ST. Comparing the effects of feeding a grain- or a fish meal-based diet on water quality, waste production, and rainbow trout Oncorhynchus mykiss performance within low exchange water recirculating aquaculture systems. Aquac Eng. 2013;52:45-57. doi.org/10.1016/j.aquaeng.2012.08.001

FAO (Food and Agriculture Organization of the United Nations). El estado mundial de la pesca y la acuicultura. Contribución a la seguridad alimentaria y la nutrición para todos. Roma: FAO (Food and Agriculture Organization of the United Nations); 2016. p. 224.

Fenerci S, Sener E. In vivo and in vitro protein digestibility of rainbow trout (Oncorhynchus mykiss Walbaum, 1972) fed steam pressured or extruded feeds. Turk J Fish Aquat Sci. 2005:5:17-22.

Forster L. A note on the method of calculating digestibility coefficients of nutrients provided by single ingredients to feeds of aquatic animals. Aquac Nutr. 1999;5(2):143-5. https://doi.org/10.1046/j.1365-2095.1999.00082.x.

Garmendia F, Pando R, Ronceros G. Efecto del aceite de sacha inchi (Plukenetia volúbilis L.) sobre el perfil lipídico en pacientes con hiperlipoproteinemia. Rev Peruana de Medicina Experimental y Salud. Publica. 2011;28:628-32.

Gatlin MD, Barrows FT, Brown P, Dabrowski K, Gaylord TG, Hardy RW, Herman E, Hu G, Krogdahl A, Nelson R, Overturf K, Rust M, Sealey W, Skonberg D, Souza EJ, Stone D, Wilson R, Wurtele E. Expanding the utilization of sustainable plant products in aquafeeds: a review. Aquac Res. 2007;38:551-79. https://doi. org/10.1111/j.1365-2109.2007.01704.x.

Gaylord GT, Barrows FT, Overturf KE, Liu K, Hu G. An overview of progress toward developing and all plant-based diet for rainbow trout. Bull Fish Res Agen. 2010;31:9-14.

Gaylord GT, Barrows FT, Rawles SD. Apparent digestibility of gross nutrients from feedstuffs in extruded feeds for rainbow trout, Oncorhynchus mykiss. J World Aquacult Soc. 2008;39(6):827-34. https:/doi.org/10.1111/j.1749-7345.2008.00220.x

Gaylord GT, Barrows FT, Teague AM, Johansen KA, Overturf KE, Shepherd B. Supplementation of taurine and methionine to all-plant protein diets for rainbow trout (Oncorhynchus mykiss). Aquaculture. 2007;269(1-4):514-24. doi. org/10.1016/j.aquaculture.2007.04.011

Glencross B. A comparison of the digestibility of diets and ingredients fed to rainbow trout (Oncorhynchus mykiss) or barramundi (Lates calcarifer) - the potential for inference of digestibility values among species. Aquac Nutr. 2011;17:e207-e2015. https://doi.org/10.1111/j.1365-2095.2010.00752.x.

Glencross BD, Booth M, Allan GL. A feed is only as good as its ingredients - a review of ingredient evaluation strategies for aquaculture feeds. Aquac Nutr. 2007;13:17-34. https://doi.org/10.1111/j.1365-2095.2007.00450.x.

Gomes EF, Rema P, Kaushik SJ. Replacement of fish meal by plant proteins in the diet of rainbow trout (Oncorhynchus mykiss): digestibility and growth performance. Aquaculture. 1995;130:177-86.

Gutiérrez LF, Rosada LM, Jiménez A. Chemical composition of Sacha Inchi (Plukenetia volúbilis L.) seeds and characteristics of their lipid fraction. Grasas Aceites. 2011;62(1):8. https://doi.org/10.3989/gya044510.

Kaushik SJ, Cravedi JP, Lalles JP, Sumpter J, Fauconneau B, Laroche M. Partial or total replacement of fish meal by soybean protein on growth, protein utilization, potential estrogenic or antigenic effects, cholesterolemia and flesh quality in rainbow trout, Oncorhynchus mykiss. Aquaculture. 1995;133(3-4): 257-74. dx.doi.org/10.1016/0044-8486(94)00403-B

Krogdahl A, Penn M, Thorsen J, Refstie S, Bakke AM. Important antinutrients in plant feedstuffs for aquaculture: an update on recent findings regarding responses in salmonids. Aquac Res. 2010;41:333-44.

Kumar V, Makkar HPS, Becker K. Nutritional, physiological and haematological responses in rainbow trout (Oncorhynchus mykiss) juveniles fed detoxified Jatropha curcas kernel meal. Aquac Nutr. 2011;17(4):451-67. https://doi.org/ 10.1111/j.1365-2095.2010.00825.x.

Lech GP, Reigh RC. Plant products affect growth and digestive efficiency of cultured Florida pompano (Trachinotus carolinus) fed compounded diets. PLoS One. 2012;7(4):e34981. https://doi.org/10.1371/journal.pone.0034981.

$\mathrm{Li} \mathrm{MH}$, Peterson BC, Janes CL, Robinson EH. Comparison of diets containing various fish meal levels on growth performance, body composition, and insulin-like growth factor-l of juvenile channel catfish Ictalurus punctatus of different strains. Aquaculture. 2006;253(1-4):628-35. doi.org/10.1016/j. aquaculture.2005.09.024

Lund I, Dalsgaard J, Tolderlund H, Holm J, Jokumsen A. Replacement of fish meal with a matrix of organic plant proteins in organic trout (Oncorhynchus mykiss) 
feed, and the effects on nutrient utilization and fish performance. Aquaculture. 2011;321:259-66. https://doi.org/10.1016/j.aquaculture.2011.09.028.

Molina-Poveda C, Cárdenas R, Jover M. Evaluation of amaranth (Amaranthus caudatus L.) and quinoa (Chenopodium quinoa Willd) protein sources as partial substitutes for fish meal in Litopenaeus vannamei grow-out diets. Aquac Res. 2015;48:822-35. https://doi.org/10.1111/are.12926.

Muñoz A, Segovia E, Futagawa M, Marchant C, Flores H. Coeficientes de digestibilidad total y de proteínas en alimentos experimentales para juveniles de Oplegnathus insignis (Kner, 1867) (Perciformes, Oplegnathidae). Lat Am J Aquat Res. 2015;43(2):304-8

NRC (National Research Council). Nutrient requirements of fish and shrimp. Washington, DC: The National Academies Press; 2011. p. 392. https://doi.org/ 10.17226/13039

Pfeffer E, Kinzinger S, Rodehutscord M. Influence of the proportion of poultry slaughter by-products and of untreated or hydrothermically treated legume seeds in diets for rainbow trout, Oncorhynchus mykiss (Walbaum), on apparent digestibilities of their energy and organic compounds. Aquac Nutr. 1995; (2):111-7. https://doi.org/10.1111/j.1365-2095.1995.tb00026.x.

Prolla DRI, Barbosa RG, Veeck APL, Augusti PR, da Silva LP, Ribeiro ND, Emanuelli T. Cultivar, harvest year, and storage conditions affecting nutritional quality of common Beans (Phaseolus vulgaris L.). Ciênc. Tecnol. Aliment., Campinas. 2010;30(Supl.1):96-102.

Repo-Carrasco R, Acevedo de La Cruz A, Icochea Alvarez JC, Chemical KH. Functional characterization of kañiwa (Chenopodium pallidicaule) grain, extrudate and bran. Plant Feeds Hum Nutr. 2009;64(2):94-101. https://doi. org/10.1007/s11130-009-0109-0.

Repo-Carrasco R, Espinoza C, Jacobsen SE. Nutritional value and use of the Andean crops quinoa (Chenopodium quinoa) and kañiwa (Chenopodium pallidicaule). Food Rev Intl. 2003;19(1-2):179-89. https://doi.org/10.1081/FRl-120018884. Rodehutscord M, Borchert F, Gregus Z, Pack M, Pfeffer E. Availability and utilization of free lysine in rainbow trout Oncorhynchus mykiss. 1. Effect of dietary crude protein level. Aquaculture. 2000;187:163-76. https://doi.org/10 1016/S0044-8486(99)00389-0

Rodríguez-Miranda J, Ramírez-Wong B, Vivar-Vera MA, Solís-Soto A, GómezAldapa CA, Castro-Rosas J, Medrano-Roldan H, Delgado-Licon E. Efecto de la concentración de harina de frijol (Phaseolus vulgaris L.), contenido de humedad y temperatura de extrusión sobre las propiedades funcionales de alimentos acuícolas. Rev Mexicana de Ingeniería Química. 2014;13(3):649-63.

Ruiz C, Díaz C, Anaya J, Rojas R. Análisis proximal, antinutrientes, perfil de ácidos grasos y de aminoácidos de semillas y tortas de 2 especies de sacha inchi (Plukenetia volubilis y Plukenetia huayllabambana). Rev Soc Quim Perú. 2013;79(1):29-36.

SAS Institute Inc. SAS/STAT 9.1 User's Guide. Cary: SAS Institute Inc; 2004 . p. 5121.

Scott T, Boldaji F. Comparison of inert markers [chromic oxide or insoluble ash (Celite)] for determining apparent metabolizable energy of wheat- or barleybased broiler diets with or without enzymes. Poult Sci. 1997;76(4):594-8. https://doi.org/10.1093/ps/76.4.594.

Sugiura SH, Dong FM, Rathbone CK, Hardy RW. Apparent protein digestibility and mineral availabilities in various feed ingredients for salmonid feeds. Aquaculture. 1998;159(3-4):177-202. https://doi.org/10.1016/S00448486(97)00177-4

Tiril SU, Karayucel I, Alagil G, Denekbasi S, Yagci FB. Evaluation of extruded chickpea, common bean and red lentil meal as protein source in diets for juvenile rainbow trout (Oncorhynchus mykiss). J Anim Vet Adv. 2009; 8(10):2079-86.

\section{Ready to submit your research? Choose BMC and benefit from}

- fast, convenient online submission

- thorough peer review by experienced researchers in your field

- rapid publication on acceptance

- support for research data, including large and complex data types

- gold Open Access which fosters wider collaboration and increased citations

- maximum visibility for your research: over $100 \mathrm{M}$ website views per year

At BMC, research is always in progress.

Learn more biomedcentral.com/submissions 